SJîñn Jurnal

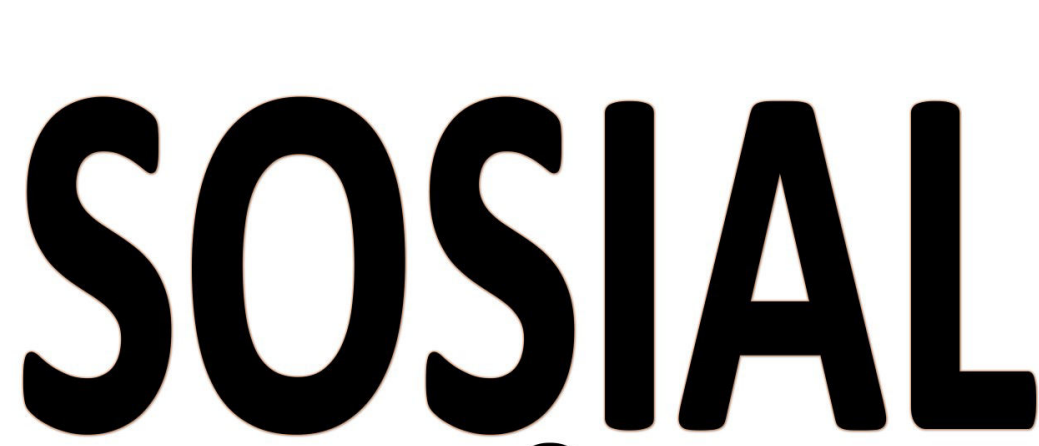

P-ISSN: 2356-1459 E-ISSN: 2654-9050 Vol. 7 No. 5 (2020)
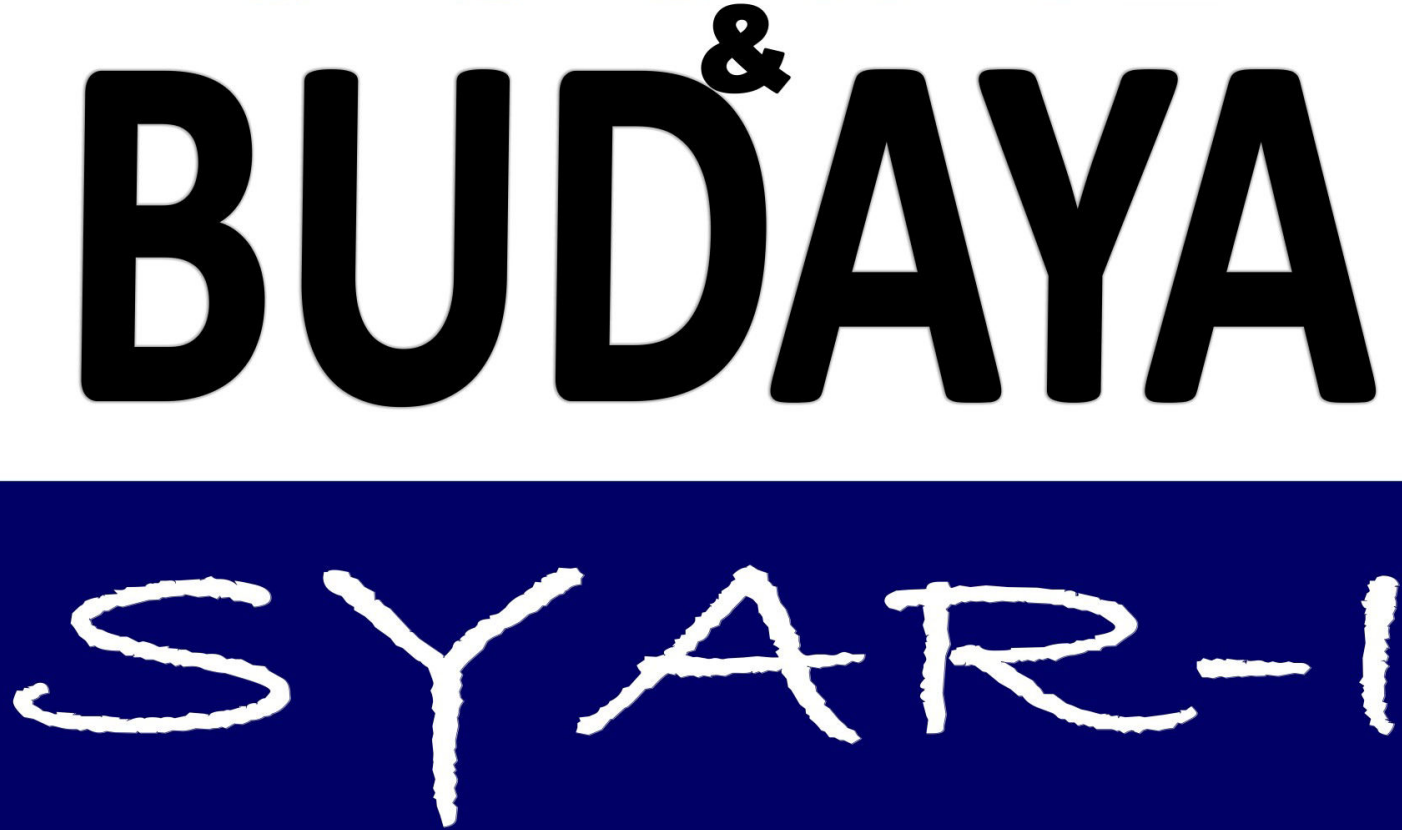

Dampak Covid-19 pada Pendidikan di Indonesia: Sekolah, Keterampilan, dan Proses Pembelajaran Rizqon Halal Syah Aji

Peran Preventif Pemimpin Dalam Pencegahan Penyebaran COVID-19; Strategi Syaykh Al-Zaytun Di Ma'had Al-Zaytun dan Kontribusinya Terhadap Masyarakat Sekitar Imam Prawoto, Siti Ngainnur Rohmah, Fitri Rachmiati Sunarya

Dari Jabariyah, ke Qadariyah, hingga Islam Progresif: Respons Muslim atas Pandemi COVID-19 di Indonesia Nur Hidayah

Transparansi Kebijakan Publik Sebagai Strategi Nasional Dalam Menanggulangi Pandemi Covid-19 Afni Regita Cahyani Muis

Peran Majelis Ulama Indonesia Dalam Mitigasi Pandemi Covid-19;

(Tinjauan Tindakan Sosial dan Dominasi Kekuasaan Max Weber)

Muhamad Agus Mushodiq, Ali Imron

Optimalisasi Upaya Pemerintah Dalam Mengatasi Pandemi Covid 19 Sebagai Bentuk Pemenuhan Hak Warga Negara

Bima Jati, Gilang Rizki Aji Putra

Pandangan Keagamaan Majelis Ulama Indonesia Kabupaten Bogor Terkait Kewajlban Menjaga Diri, Pelaksanaan Shalat Jumat dan Pengurusan Mayit Dalam Situasi Darurat Penyebaran Covid-19 Ahmad Mukri Aji 


\title{
Peran Preventif Pemimpin Dalam Pencegahan Penyebaran COVID-19; Strategi Syaykh Al-Zaytun di Ma'had Al-Zaytun dan Kontribusinya Terhadap Masyarakat Sekitar*
}

\author{
Imam Prawoto, ${ }^{1}$ Siti Ngainnur Rohmah ${ }^{2}$ Fitri Rachmiati Sunarya ${ }^{3}$ \\ Institut Agama Islam Al Zaytun Indonesia \\ dol $\underline{10.15408 / \text { sjsbs.v7i5.15571 }}$
}

\begin{abstract}
Leaders have a very significant role in efforts to prevent the spread of the corona pandemic in the surrounding environment. Both leaders on a national and regional scale. Included in this are the leaders of CSOs, universities, schools and Islamic boarding schools. This article describes the strategy of Shaykh Al-Zaytun in preventing the spread of the Corona Pandemic in Ma'had Al-Zaytun and Al-Zaytun's Contribution to the Surrounding Communities. The method used is a qualitative method with a literature approach. The data obtained comes from lectures and public lectures, apart from various books and scientific journals.
\end{abstract}

Keywords: Leader, Covid-19, Preventive Action

\begin{abstract}
Abstrak
Para pemimpin memiliki peranan yang sangat signifikan dalam upaya tindakan preventif penyebaran pandemi corona di lingkungan sekitarnya. Baik pemimpin dalam skala nasional maupun daerah. Termasuk dalam hal ini adalah para pimpinan ormas, perguruan tinggi, sekolah dan pondok pesantren. Artikel ini memaparkan strategi Syaykh Al-Zaytun dalam pencegahan penyebaran Pandemi Corona di Ma'had Al-Zaytun dan Kontribusi AlZaytun terhadap Masyarakat Sekitar. Metode yang digunakan adalah metode kualitatif dengan pendekatan literature. Data yang didapat bersumber dari ceramah dan kuliah umum, selain dari berbagai buku dan jurnal ilmiah.
\end{abstract}

Kata Kunci: Pemimpin, Covid-19, Tindakan Preventif

\footnotetext{
* Diterima: 17 Maret 2020, Revisi: 22 Maret 2020, Diterbitkan 17 Mei 2020.

${ }^{1}$ Imam Prawoto adalah Dosen Institut Agama Islam Al Zaytun Indonesia, Mekarjaya, Gantar, Indramayu, Jawa Barat, alamat email:imam.prawoto@iai-alzaytun.ac.id.

${ }^{2}$ Siti Ngainnur Rohmah adalah Dosen Institut Agama Islam Al Zaytun Indonesia, Mekarjaya, Gantar, Indramayu, Jawa Barat, alamat email: siti.ngainnur@iai-alzaytun.ac.id.

${ }^{3}$ Fitri Rachmiati Sunarya adalah Dosen Institut Agama Islam Al Zaytun Indonesia, Mekarjaya, Gantar, Indramayu, Jawa Barat, alamat email: fitri.sunarya@iai-alzaytun.ac.id.
} 


\section{Pendahuluan}

Kontribusi dan kepedulian para pemimpin sangat dibutuhkan dalam pencegahan penyebaran pandemic virus corona. Pemimpin memiliki kedudukan dan power di mata followernya. Power ini bisa digunakan untuk mengarahkan dan mempengaruhi orang-orang yang ada di bawah kepemimpinannya. Berkenaan dengan pandemic corona ini, para pemimpin dapat berkontribusi membantu pemerintah dalam upaya pencegahan penyebaran pandemic virus corona yang ada di lingkungan sekitarnya. Hal ini dapat dilakukan dengan membuat strategi dan kebijakan yang harus dilaksanakan oleh orang-orang yang dipimpinnya. Dalam hal ini Syaykh AlZaytun, Dr. Al-Ustadz (Hon. M.S.U.) A.S. Panji Gumilang, M.P., selaku pendiri, dan sekaligus pimpinan Pondok Pesantren Ma'had Al-Zaytun telah memberikan contoh konkrit strategi menghadapi pandemic corona, sekaligus upaya preventif COVID-19.

Permasalahan dalam tulisan ini adalah adakah peranan pemimpin dalam upaya preventif penyebaran COVID-19? Kebijakan apa saja yang dilakukan oleh Syaykh Al-Zaytun agar Al-Zaytun tetap survive dan exist di tengah pandemic corona? Strategi apa yang ditempuh oleh Syaykh Al-Zaytun dalam upaya preventif penyebaran COVID-19? Tulisan ini diharapkan bisa menjadi salah satu bahan acuan untuk mengetahui peranan pemimpin dalam upaya preventif penyebaran COVID-19.

Sumber utama tulisan ini adalah pidato-pidato Syaykh Al-Zaytun, Dr. AlUstadz (Hon. M.S.U.) A.S. Panji Gumilang, M.P., terkait pandemic corona dan observasi $^{4}$ di lingkungan pondok pesantren Ma'had Al-Zaytun. Pendekatan yang digunakan dalam tulisan ini adalah pendekatan interpretasi (interpretative approach), yakni menyelami pemikiran seorang tokoh yaitu pemikiran yang tertuang dalam pidato-pidato Syaykh Al-Zaytun, Dr. Al Ustadz (Hon. M.S.U.) A.S. Panji Gumilang, M.P., terkait pandemic corona untuk menangkap nuansa makna yang dimaksud secara khas sehingga tercapai suatu pemahaman yang utuh dan benar. Artikel ini menggunakan metode kualitatif ${ }^{5}$ sebagai analisis data. Di samping itu, peneliti juga menggunakan pendekatan komparatif yaitu membandingkan pendapat Syaykh AlZaytun dengan informasi di masyarakat yang terkait tentang COVID-19.

\section{Pembahasan}

\section{Kilas Balik Ma'had Al-Zaytun}

Latar belakang dan tujuan pendirian Pondok Pesantren Ma'had Al Zaytun yang bermula dari Yayasan Pesantren Indonesia (YPI) yang kemudian menjadi besar dan saat ini menaungi Pondok Pesantren Ma'had Al-Zaytun. Ma'had Al-Zaytun merupakan sebuah institusi pendidikan milik ummat Islam, timbul dari bangsa

${ }^{4}$ Objek yang dievaluasi bisa bersifat nyata(tangible) seperti benda-benda, gerakan, perilaku. Tetapi objek juga bisa bersifat intangible seperti suasana atau situasi. Prasetya Irawan Penelitian Kualitatif $\mathcal{E}$ Kuantitatif untuk Ilmu-ilmu Sosial, (Jakarta: DIA FISIP UI, 2006 M.), 69.

${ }^{5}$ Metode kualitatif adalah prosedur penelitian yang menghasilkan data deskriptif berupa katakata tertulis atau lisan dari orang-orang dan pelaku yang dapat diamati. Lexy J. Moleong, Metodologi Penelitian Kualitatif (Bandung: PT. Remaja Rosda Karya, 2004), 4. 
Indonesia dan untuk bangsa Indonesia juga. Hal inilah yang menyebabkan elemenelemen Ma'had Al-Zaytun ada di mana-mana dalam kalangan ummat dan bangsa seluruhnya. Pendirian Ma'had Al-Zaytun dilatarbelakangi oleh perjalanan panjang sejarah bangsa dan sejarah ummat manusia secara luas dan panjang. Bangsa Indonesia mengalami sejarah penjajahan yang sangat panjang selama tiga setengah abad, terhitung sejak masuknya bangsa Belanda ke Banten tahun 1596 hingga Proklamasi Kemerdekaan 1945. Bangsa Indonesia dalam menjalankan pemerintahan sendiri selama lebih dari setengah abad, belum mencapai kemajuan yang berarti, khususnya di bidang pendidikan. Begitu juga sejarah bangsa-bangsa di dunia sepanjang abad 20, terjadinya blok-blok besar yang saling ingin menguasai satu dengan yang lainnya, yang akhirnya dimenangkan oleh blok Barat. Berbagai peristiwa dan kejadian sejarah, baik nasional maupun internasional mengilhami pemikiran sejumlah ummat bangsa Indonesia untuk mendirikan suatu lembaga pendidikan yang mampu menjawab tantangan sejarah dan menciptakan keseimbangan intelektual, sehingga dengannya keseimbangan dan perdamaian dapat diwujudkan dalam lingkungan kehidupan ummat manusia. ${ }^{6}$

Proses pendirian Pondok Pesantren Ma'had Al-Zaytun ${ }^{7}$ diawali dengan perenungan, mimpi dan cita-cita panjang dari pendiri Al-Zaytun; The Founding Father of Al-Zaytun Y.A.B. Al-Ustadz Dr. (Hon.MSU) A.S. Panji Gumilang, M.P., dan sahabatsahabatnya. Perenungan dan perjuangan tersebut adalah mengenai betapa perlunya wadah pendidikan sebagai wahana untuk mengajak bangsa Indonesia menjadi manusia yang intelek, menguasai sains dan teknologi, sanggup mengimbangi kemajuan bangsa lain, namun memiliki moral tinggi, berwawasan internasional, kental dengan rasa kemanusiaan, toleransi, dan perdamaian.

Untuk mewujudkan mimpi-mimpinya, The Founding Father of Al-Zaytun Y.A.B. Al-Ustadz Dr. (Hon.MSU) A.S. Panji Gumilang menerapkan 3 prinsip yaitu khayal (bermimpi/membuat ide), shuwar (membuat rancangan tertulis), dan 'amal (action), serta didukung, bahkan dijadikan sebagai gaya/model oleh segenap sahabat-sahabat foundernya. Pada tataran khayal, para founder mengangankan perlunya perdamaian dunia, karena abad ke-20 yang lalu, dunia diliputi berbagai peperangan. Maka pada abad 21 yang merupakan tonggak awal memasuki millennium ke-3 diharapkan tidak terjadi lagi peperangan di dunia ini.

Dunia dalam skala kecil, yakni Indonesia, harus damai. Untuk menciptakan perdamaian dunia, diperlukan keseimbangan, yaitu keseimbangan antara agama dan intelektual. Keseimbangan tersebut dapat diwujudkan dengan menciptakan pendidikan yang baik. Pendidikan yang bervisi mengembangkan toleransi dan perdamaian.

${ }^{6}$ Yayasan Pesantren Indonesia, Al-Zaytun Pusat Pendidikan Pengembangan Budaya Toleransi dan Perdamaian (Indramayu: Al-Zaytun Press, 2014).

7 Yayasan Pesantren Indonesia, Al-Zaytun Pusat Pendidikan Pengembangan Budaya Toleransi dan Perdamaian (Indramayu: Al-Zaytun Press, 2014) dan Lembaga Kesejahteraan Masjid Masjid Rahmatan Lil 'alamiin, Majalah Al-Zaytun dalam periode 1999 -2012. 
Pada tahap persiapan, kegiatan intinya adalah pembentukan kelembagaan beserta legalitasnya. Bersamaan dengan hari Raya Iedul Adha, 10 Dzulhijjah 1423H atau tanggal 1 Juni 1993 The Founding Father of Al-Zaytun Y.A.B. Al-Ustadz DR. (Hon.MSU) A.S. Panji Gumilang, M.P., dan para sahabatnya bersepakat untuk mendirikan sebuah badan hukum yang dinamakan Yayasan Pesantren Indonesia (YPI). Kesepakatan ini secara resmi dituangkan dalam akta pendirian YPI tertanggal 25 Januari 1994 No. 61 oleh notaris Ny. Ii Rokayah Sulaeman, S.H. dan terdaftar di Kepaniteraan Pengadilan Negeri Subang pada tanggal 28 Januari 1994. YPI pertama kalinya berkantor di Kabupaten Subang. Selanjutnya, pada tanggal 17 Mei 1995 didirikan cabang YPI di Kabupaten Indramayu yaitu dengan nomor akte 34 oleh notaris yang sama dan didaftarkan di Kepaniteraan Pengadilan Negeri Indramayu pada tanggal 22 Mei 1995 dengan alamat Desa Mekarjaya, Kecamatan Haurgeulis, Kabupaten Indramayu, Jawa Barat dan kini telah disempurnakan dengan Akta Pernyataan Keputusan Rapat Yayasan Pesantren Indonesia Nomor 6; tanggal 24 Januari 2011 oleh Notaris Tommy Soerjakantjana, S.H., M.Kn., dan telah tercatat di Kementerian Hukum dan Hak Azasi Manusia Republik Indonesia, Direktorat Jenderal Administrasi Hukum Umum dengan Nomor: AHU-AH.01.08-219.8

Tahap kedua adalah pembelian area lahan tanah, pembangunan infrastruktur dan sarana prasarana, untuk merealisasikan satu per satu rencana yang ada pada site plan. Pembangunan fisik dimulakan pada 13 Agustus 1996 yang dimulai dengan penataan dan lingkungan kampus. Selanjutnya bangunan fisik yang sudah terealisir sebelum dimulainya kegiatan pembelajaran (kurun waktu tahun 1996 - 1999) adalah berupa infrastruktur jalan kompleks kampus, 2 (dua) gedung pembelajaran (Abu Bakar Ash-Shiddiq dan Umar Ibnu Khaththab, 1 (satu) gedung asrama pelajar (AlMusthafa), Masjid Al-Hayat, rumah makan pelajar, sarana umum (warpostel, garment, kantin umum, toserba) dan satu buah lapangan sepak bola tertutup, yaitu Stadion Palagan Agung, serta 11 lapangan sepak bola terbuka. Walhasil pada tahapan ini telah tersedia sarana minimal untuk menyelenggarakan pendidikan.

Tahapan berikutnya penyelenggaraan pendidikan pada tahun 1999, yang diawali dengan rekruitmen guru dan santri.9 Tahun pertama guru yang direkrut sebanyak 139 orang, terdiri dari 77 guru laki-laki, 29 guru perempuan dan 26 murabbi (pembimbing) laki-laki, 7 murabbi perempuan. Untuk rekruitmen santri, Yayasan Pesantren Indonesia mengirim perwakilan-perwakilan ke seluruh Provinsi di tanah air termasuk ke negeri Jiran, Malaysia dan Singapura. Perwakilan ini bertugas untuk memperkenalkan Ma'had Al-Zaytun kepada khalayak ramai sekaligus melakukan rekruitmen dan bimbingan terhadap calon santri.

Santri angkatan pertama sebanyak 1.488 orang terdiri dari 856 rijal dan 632 nisa yang berasal dari seluruh provinsi (termasuk Timor-Timur; sekarang Timor Leste)

8 Yayasan Pesantren Indonesia, Al-Zaytun Pusat Pendidikan Pengembangan Budaya Toleransi dan Perdamaian (Indramayu: Al-Zaytun Press, 2014) dan Lembaga Kesejahteraan Masjid Masjid Rahmatan Lil 'alamiin, Majalah Al-Zaytun dalam periode 1999 -2012.

${ }^{9}$ Yayasan Pesantren Indonesia, Al-Zaytun Pusat Pendidikan Pengembangan Budaya Toleransi dan Perdamaian (Indramayu: Al-Zaytun Press, 2014) dan Lembaga Kesejahteraan Masjid Masjid Rahmatan Lil ‘alamiin, Majalah Al-Zaytun dalam periode 1999 -2012. 
yang ada di Indonesia dan dari Malaysia. Jenjang pendidikan pertama yang diselenggarakan adalah tingkat menengah pertama (Madrasah Tsanawiyah). Pembukaan pembelajarannya dilaksanakan pada tanggal 1 Juli 1999 oleh Menteri Pertanian Republik Indonesia Prof. Dr. Soleh Solahuddin; dan tanggal 1 Juli sebagai awal tahun pembelajaran.

Peresmian kampus Ma'had Al-Zaytun dilaksanakan Jum'at tanggal 27 Agustus 1999 M, bertepatan dengan 18 Jumada al-Ula 1420 H, oleh Presiden Republik Indonesia ke-3 Prof. Ing. BJ Habibie. Visi dan Misi Ma'had Al-Zaytun ${ }^{10}$ adalah Perbaikan kualitas pendidikan umat yang tersimpul di dalam motto: "Ma'had AlZaytun Pusat Pendidikan dan Pengembangan Budaya Toleransi serta Pengembangan Budaya Perdamaian". Arah dan Tujuan Ma'had Al-Zaytun adalah mempersiapkan peserta didik untuk beraqidah yang kokoh kuat terhadap Allah dan Syari'at-Nya, menyatu di dalam tauhid, berakhlaq al-karimah, berilmu pengetahuan yang luas, berketerampilan tinggi yang tersimpul dalam bashthotan fil 'ilmi wal jismi sehingga sanggup siap dan mampu untuk hidup secara dinamis di lingkungan negara bangsanya dan masyarakat antar bangsa dengan penuh kesejahteraan dan kebahagiaan duniawi maupun ukhrowi.

Landasan Ma'had Al-Zaytun adalah Pesantren spirit but modern system, mendidik dan membangun semata-mata beribadah kepada Allah. Spesifikasi/Ciri Khas Ma'had Al-Zaytun adalah penguasaan Al-Qur'an secara mendalam, terampil berkomunikasi menggunakan bahasa-bahasa antar bangsa yang dominan, berpendekatan ilmu pengetahuan, berketerampilan teknologi dan fisik, berjiwa mandiri, penuh perhatian terhadap aspek dinamika kelompok dan bangsa, berdisiplin tinggi serta berkesenian yang memadai.

\section{Sarana Pendukung Ma'had Al-Zaytun}

Sarana Fisik untuk Pendidikan terdiri dari Gedung pembelajaran. 1) Gedung pembelajaran Abu Bakar Al-Shiddiq. Gedung ini dibangun awal tahun 1996, selesai tahun 1998. Luas bangunannya $10.000 \mathrm{~m}^{2}$ terdiri 4 lantai bangunan, terdapat 42 lokal kelas dengan ukuran $8 \mathrm{~m}$ X $12 \mathrm{~m}$. 2) Gedung pembelajaran Umar Ibnu Khaththab. Gedung ini dibangun awal tahun 1996, selesai tahun 2000. Luas bangunannya 12.500 $\mathrm{m}^{2}$ terdiri 5 lantai bangunan, terdapat 58 lokal kelas dengan ukuran $8 \mathrm{~m} \mathrm{X} 12 \mathrm{~m} .3$ ) Gedung pembelajaran Utsman Ibnu Affan. Gedung ini dibangun awal tahun 2000, selesai tahun 2001. Luas bangunannya $16.000 \mathrm{~m}^{2}$ terdiri 5 lantai bangunan, terdapat 100 lokal kelas dengan ukuran $8 \mathrm{~m}$ X $12 \mathrm{~m}$. 4) Gedung pembelajaran Ali bin Abi Thalib. Gedung ini dibangun awal tahun 2001, selesai tahun 2002. Luas bangunannya 18.800 $\mathrm{m} 2$ terdiri 5 lantai bangunan, terdapat 100 lokal kelas dengan ukuran $8 \mathrm{~m}$ X $12 \mathrm{~m} .5$ ) Gedung pembelajaran Tan Sri Dato' Ismail Hussein. Gedung ini terdiri atas 10 ruang pembelajaran (kelas), 12 ruang asrama, dua ruang asrama guru nisa dan rijal, ruang

10 Yayasan Pesantren Indonesia, Al-Zaytun Pusat Pendidikan Pengembangan Budaya Toleransi dan Perdamaian (Indramayu: Al-Zaytun Press, 2014) dan Lembaga Kesejahteraan Masjid Masjid Rahmatan Lil 'alamiin, Majalah Al-Zaytun dalam periode 1999 -2012; Lembaga Kesejahteraan Masjid Masjid Rahmatan Lil ‘alamiin, Majalah Al-Zaytun dalam periode $1999-2012$. 
administrasi, dan ruang serbaguna. 6) Gedung perkuliahan Jenderal Besar H. M. Soeharto. Gedung ini dibangun awal tahun 2002, selesai tahun 2005. Luas bangunannya $18.800 \mathrm{~m}^{2}$ terdiri 6 lantai bangunan, terdapat 100 lokal kelas dengan ukuran $8 \mathrm{~m} \mathrm{X} 12 \mathrm{~m} \cdot{ }^{11}$

Sarana pendukung lainnya adalah gedung asrama. Di antaranya: 1) Asrama AlMusthafa. Gedung ini dibangun awal tahun 1997, selesai tahun 1999. Luas bangunannya $22.000 \mathrm{~m}^{2}$ terdiri 5 lantai bangunan, terdapat 170 kamar tidur (@ $72 \mathrm{~m}^{2}$ alokasi untuk 10 santri). Kelengkapan unit kamar tidur terdiri dari lima tempat tidur susun, lemari pakaian, ruang belajar, meja kursi belajarm rak buku perpustakaan lengkap dengan buku perpustakaan sejumlah pelajaran dan sejumlah santri, tiga buah kamar mandi dan wastefel dan dispenser air minum santri. 2) Asrama Al-Fajr. Ukuran dan fasilitas Asrama Al-Fajr sama dengan Asrama Al-Musthafa. 3) Asrama Al-Nur. Ukuran dan fasilitas Asrama Al-Nur sama dengan Asrama Al-Musthafa. 4) Asrama AlMadani. Gedung ini dibangun awal tahun 2000, selesai tahun 2002. Luas bangunannya $28.000 \mathrm{~m}^{2}$ terdiri 6 lantai bangunan, terdapat 204 kamar tidur (@ $84 \mathrm{~m}^{2}$ alokasi untuk 12 santri). Kelengkapan unit kamar tidur terdiri dari lima tempat tidur susun, lemari pakaian, ruang belajar, meja kursi belajar rak buku perpustakaan lengkap dengan buku perpustakaan sejumlah pelajaran dan sejumlah santri, tiga buah kamar mandi dan wastefel dan dispenser air minum santri. ${ }^{12}$

Gedung asrama memiliki fasilitas pendukung. Fasilitas pendukung asrama, di antaranya adalah 1) kitchen. 2) rumah makan santri, dan 3) laundry. Selain itu ada juga 2 masjid. 1) Masjid Al-Hayat, merupakan masjid persiapan atau Masjid I'dadi dengan luas $5.000 \mathrm{~m}^{2}$ yang dapat menampung 6.000 jama'ah. 2) Masjid Rahmatan Lil'Alamin, dalam proses pembangunan, terdiri dari 6 lantai, bangunan menempati areal seluas 6,5 ha yang dapat menampung 100.000 jama'ah. Ada juga sarana olah raga (sarana olah raga ada 2 blok di arena pembelajaran, masing-masing 6,5 ha), perkhidmatan kesihatan (perkhidmatan kesehatan yang berfungsi memberikan pelayanan kesehatan kepada seluruh penghuni Ma’had Al-Zaytun), Wisma Tamu Al-Ishlah (Wisma tamu Al-Ishlah berada di atas tanah seluas $6.500 \mathrm{~m}^{2}$ lima lantai dengan 150 kamar tidur dilengkapi coffee shop, meeting room dan fasilitas pendukung lainnya), bangunan peternakan (bangunan peternakan Ma'had Al-Zaytun di antaranya bangunan peternakan sapi perah dan sapi potong, kambing perah dan kambing potong), Laboratorium Kultur Jaringan Lahan perkebunan (di lahan ini dikembangkan tanaman jati emas, jati genjah, mangga, tin, zaytun, dan tanaman buah atau tanaman keras lainnya), Danau buatan/empang (Danau buatan/empang digunakan untuk peternakan ikan dan sebagai penyeimbang air tanah yang merupakan pendukung pengairan di lingkungan Ma'had

11 Yayasan Pesantren Indonesia, Al-Zaytun Pusat Pendidikan Pengembangan Budaya Toleransi dan Perdamaian (Indramayu: Al-Zaytun Press, 2014) dan Lembaga Kesejahteraan Masjid Masjid Rahmatan Lil 'alamiin, Majalah Al-Zaytun dalam periode 1999 -2012.

12 Yayasan Pesantren Indonesia, Al-Zaytun Pusat Pendidikan Pengembangan Budaya Toleransi dan Perdamaian (Indramayu: Al-Zaytun Press, 2014) dan Lembaga Kesejahteraan Masjid Masjid Rahmatan Lil 'alamiin, Majalah Al-Zaytun dalam periode 1999 -2012. 
Al-Zaytun berupa 4 buah empang yang berukuran 100 m X 100 m dengan kedalaman 6 meter)..$^{13}$

Sarana dan Prasarana lainnya. Sarana dan prasarana pendukung penting lain di antaranya adalah sebagai berikut: a) Industri tahu dan tempe. b) Industri pengolahan pakan ternak. c) Istana Beras d) Pabrik Mebeler. e) Percetakan. f) Toko Kantin umum. g) Warung Telepon. h) Warung Pos. i) Barbershop. j) Mess karyawan. k) Laboratorium komputer. 1) Jaringan telephone. m) Jaringan listrik dari PLN dengan back up generator listrik.

\section{Syaykh Al-Zaytun Sosok Pemimpin Kharismatik}

Syaykh Al-Zaytun merupakan sosok pemimpin yang kharismatik. Hal ini terlihat ketika beliau memberikan taushiyah, seluruh sivitas Ma'had Al-Zaytun sangat antusias menyimaknya. Baik exponen, dosen, guru, karyawan, maupun pelajar sangat respek kepada Beliau. Segala arahan, dan bimbingan beliau diterima dengan baik dan senang hati.

Syaykh Al-Zaytun memiliki talenta kepemimpinan yang kuat, ciri-cirinya di antaranya sebagai berikut:

Pertama, ber-ilmu, dan berwawasan luas serta mumpuni dalam urusan politik. ${ }^{14}$ Beliau tidak hanya cakap dalam ilmu keagamaan saja tapi juga menguasai ilmu keduniaan, seperti ilmu politik, dan ilmu pertanian. Ma'had Al-Zaytun merupakan pondok pesantren spirit yang menggunakan system modern. Untuk menopang perekonomian pesantren, maka Ma'had Al-Zaytun mengembangkan pertanian dengan teknologi modern. Hasil pertanian pun melimpah untuk memenuhi kebutuhan sivitas Ma'had Al-Zaytun. Hal ini tidak terlepas dari peran Syaykh Al-Zaytun yang memiliki ilmu pertanian berbasis teknologi modern. Beliau merupakan Master dalam bidang pertanian, karena studi strata 2 Beliau adalah bidang pertanian.

Kedua, Tubuh yang perkasa dan berjiwa kuat, untuk menghilangkan kekhawatiran dalam hati, sehingga mampu menghadapi segala persoalan dan rintangan. ${ }^{15}$ Dari awal berdiri hingga sekarang, Ma'had Al-Zaytun sering mendapatkan fitnah, dan tuduhan yang tidak baik dari orang-orang yang yang iri dan dengki. Untuk menghadapi itu semuanya, tentunya diperlukan sosok pemimpin yang gagah, tegas, dan tegar dalam menghadapi segala permasalahan yang datang. Kedua ciri-ciri kepemimpinan di atas sudah tersurat dalam Al-quran, yaitu Surat al-Baqarah [2]: 247.

" ...Nabi (mereka) berkata: "Sesungguhnya Allah telah memilih rajamu dan menganugerahinya ilmu yang Luas dan tubuh yang perkasa." Allah memberikan

13 Yayasan Pesantren Indonesia, Al-Zaytun Pusat Pendidikan Pengembangan Budaya Toleransi dan Perdamaian (Indramayu: Al-Zaytun Press, 2014) dan Lembaga Kesejahteraan Masjid Masjid Rahmatan Lil 'alamiin, Majalah Al-Zaytun dalam periode 1999 -2012.

${ }^{14}$ Muhammad 'Ali Al-Sabuni, Rawai' al-Bayan Tafsìr Ayat al-Ah\}kām min al-Qur'an (Jakarta: Dar alKutub al-Islamiyyah, 1999), Jilid 1, 209.

${ }^{15}$ Muhammad 'Ali Al-Sabuni, Rawai' al-Bayan Tafsīr Ayat al-Ah\}kām min al-Qur'an, Jilid 1, 209-210. 
pemerintahan kepada siapa yang dikehendaki-Nya. dan Allah Maha Luas pemberianNya lagi Maha mengetahui. Al-qur'an Surat al-Baqarah[2]: 247.

Ketiga, Di antara ciri-ciri seseorang yang layak menjadi pemimpin, adalah menjauhi segala perbuatan dosa, baik dosa besar maupun kecil, serta menghindarkan diri dari perbuatan keji. ${ }^{16} \mathrm{Hal}$ ini sesuai dengan Al-qur'an surat al-Najm[53]:32. "(yaitu) orang-orang yang menjauhi dosa-dosa besar dan perbuatan keji yang selain dari kesalahankesalahan kecil. .."

Dosa besar ialah setiap dosa yang penyebutannya oleh Allah di akhiri dengan ancaman neraka, murka, laknat atau adzab-Nya, atau dihukum had di dunia, atau yang pelakunya berani melakukannya tanpa merasa takut atau menyesal, atau yang berakibat terjadinya kerusakan-kerusakan besar, sekalipun dalam pandangan manusia merupakan hal yang remeh. ${ }^{17}$

Dalam kesehariannya Syaykh Al-Zaytun selalu melakukan hal-hal yang bermanfaat serta memperbanyak ibadah dan dzikir. Beliau mengamalkan dzikir asmaul husna dan asmaun nabi 201 setelah selesai sholat 5 waktu. Begitu pula yang diajarkan kepada para exponen, dosen, guru, karyawan, dan pelajar.

Keempat, Memiliki skill, keahlian yang mumpuni. ${ }^{18}$ Hal ini tersurat dalam Alqur'an surat Yusuf[12]:55. "Berkata Yusuf: "Jadikanlah aku bendaharawan negara (Mesir); Sesungguhnya aku adalah orang yang pandai menjaga, lagi berpengetahuan" ". Yusuf[12]:55

Nabi Yusuf mengajukan diri sebagai bendaharawan negara (Mesir), karena beliau mempunyai keahlian, ilmu pengetahuan, dan bisa menjaga amanah. Berdasarkan ayat ini, jika seseorang mempunyai keahlian, ilmu pengetahuan, dan bisa menjaga amanah, maka dirinya layak sebagai pemimpin. ${ }^{19}$

Syaykh Al-Zaytun memiliki banyak keahlian di antaranya skill management yayasan dan Ma'had Al-Zaytun, serta bisa menjaga amanah. Maka beliau sangat layak menjadi pemimpin karena memiliki berbagai skill dan sifat yang amanah.

Kelima, Memiliki jiwa wirausaha atau enterpreneur. Wirausaha adalah seorang yang berkemauan keras dalam bisnis yang patut menjadi teladan. ${ }^{20}$ Enterpreneur berasal dari bahasa Perancis enterprende yang berarti mengambil pekerjaan (to undertake). ${ }^{21}$ Wirausaha juga dapat diartikan seseorang yang menciptakan bisnis baru dengan mengambil risiko dan ketidakpastian demi mencapai keuntungan dan pertumbuhan bisnis dengan cara mengidentifikasi peluang dan menggabungkan sumber daya yang diperlukan untuk mendirikannya. ${ }^{22}$ Menurut Joseph Schumpeter, sebagaimana dikutip oleh William D. Bygrave Wirausaha adalah seseorang yang

16 Muhammad 'Ali Al-Sabuni, Rawai' al-Bayan Tafsīr Ayat al-Ah\}kām min al-Qur'an, Jilid III, 301.

17 Ahmad Al-Mustafa Al-Maraghi, Tafsir Al-Maraghi, (Semarang: PT. Karya Toha Putra Semarang:1993), jilid 27, 102.

18 Muhammad 'Ali Al-Sabuni, Rawai' al-Bayan Tafsīr Ayat al-Ahkām min al-Qur'an, Jilid II, 93.

${ }^{19}$ Muhammad 'Ali Al-Sabuni, Rawai' al-Bayan Tafsīr Ayat al-Ahkām min al-Qur'an, Jilid II, 90-91.

${ }^{20}$ Tarsis Tarmudji, Prinsip-prinsip Wirausaha, (Yogyakarta: Liberty, 2003 M.), hlm. 4.

${ }^{21}$ Muh. Yunus, Islam dan Wirausaha Kreatif, (Malang: UIN Press, 2008 M.), 27.

22 Thomas W. Zimmerer dan Norman Scarborough Entrepreneurship: The New Venture Formation (Prentice Hall International Inc., 1996 M.), 43. 
mendobrak system ekonomi yang ada dengan memperkenalkan barang dan jasa yang baru dengan menciptakan bentuk organisasi baru atau mengolah bahan baku baru. ${ }^{23}$ Seseorang dapat digolongkan sebagai wirausaha apabila mempunyai keyakinan diri yang tinggi dan berkeyakinan bahwa dirinya mampu mencapai sasaran yang diinginkannya. ${ }^{24}$

Seorang wirausahawan memiliki karakter percaya diri dan optimis, berorientasi pada tugas dan hasil, berani mengambil risiko dan menyukai tantangan, memiliki karakter kepemimpinan, orisinalitas, dan berorientasi ke masa depan. ${ }^{25}$ Selain mempunyai karakter seorang wirausahawan juga memiliki watak; kepercayaan diri yang kuat, ketidaktergantungan terhadap orang lain, individualistis, optimisme, kebutuhan berprestasi, berorientasi laba ketekunan dan ketabahan, tekad kerja keras,energetik, inisiatif, mampu mengambil risiko yang wajar terbuka terhadap saran dan kritik. Seorang wirausahawan harus inovatif, kreatif, fleksibel, serta memiliki visi dan perspektif ke masa depan. ${ }^{26}$

Syaykh Al-Zaytun merupakan sosok wirausahawan yang tangguh dan sukses. Hal ini dapat dilihat dari berbagai usaha yang telah didirikan di Ma'had Al-Zaytun. Di antaranya adalah PT. Samudra Mangun Kencana yang memproduksi air minum, Istana Beras/pabrik beras, garmen laundry, hotel/wisma tamu Al-Islah, mebel, toserba, perkebunan, dan lain sebagainya. Hal ini menunjukkan bahwa Syaykh Al-Zaytun adalah seorang wirausahawan yang tangguh, sukses, dan memiliki skill bisnis yang handal.

Dari paparan di atas dapat kita pahami bahwa Syaykh Al-Zaytun memiliki sifat, dan karakter kepemimpinan yang mumpuni. Sangat wajar apabila rekan-rekan pimpinan pondok pesantren yang ada di sekitar Ma'had Al-Zaytun dan Jawa Barat sangat menaruh simpati kepada beliau. Begitu pun para exponen, dosen, guru, karyawan, maupun pelajar sangat respek dan ta'dzim kepada Beliau.

\section{Strategi dan Kebijakan Syaykh Al-Zaytun dalam pencegahan Penyebaran Pandemic Corona di Ma'had Al-Zaytun.}

\section{Strategi fisik}

\section{a. Pengaturan dalam hal logistic/makanan}

Sivitas Ma'had Al-Zaytun hanya boleh makan makanan yg disediakan Ma'had Al-Zaytun saja selama lockdown, tidak boleh jajan di luar. Hal ini untuk memastikan seluruh sivitas Ma'had Al-Zaytun mengkonsumsi makanan dan minuman yang higinis dan sehat. Makan malam pada pukul 17.00. Pada pukul 17.25 Syaykh Al-Zaytun keliling mengecek seluruh lingkungan Ma'had Al-Zaytun khususnya asrama. Pihak luar sementara tidak boleh mengirimkan paket makanan kepada Sivitas Ma'had Al-

${ }^{23}$ William D. Bygrave, The Portable MBA in Intrepreneurship, (New York: John Willey \& Sons 1994 M.), 1.

${ }^{24}$ Sadono Sukirno et al. Pengantar Bisnis, (Jakarta: Prenadamedia, 2004 M.), 367.

${ }^{25}$ Buchari Alma, Kewirausahaan, (Bandung: Alfabeta, 2013 M.)24-25.

${ }^{26}$ Idri, Hadis Ekonomi, (Jakarta: Prenada Media, 2016 M.), 303. 
Zaytun. Jadi, Sivitas Ma'had Al-Zaytun hanya konsumsi makanan dan minuman yang disediakan oleh Ma'had Al-Zaytun saja.

Pada masa pandemic corona yang sedang dihadapi oleh seluruh manusia di muka bumi ini, di dalamnya ada orang-orang muslim yang pada bulan Ramadhan melaksanakan shaum Ramadhan. ${ }^{27}$ Pada bulan Ramadhan menurut ketetapan para ahli kesehatan setiap muslim harus fit, kualitas kesehatannya harus baik. Unsur asupan harus memenuhi kriteria kesehatan. Intinya asupan makanan terdiri dari karbohidrat, sebagian protein, vitamin, serat, dan yang lainnya.

Sivitas Ma'had Al-Zaytun pada shaum ramadhan ini harus mempunyai ketahanan fisik, maka mulai buka puasa di hari pertama puasa sudah mulai beralih dari yang biasanya makan nasi ke makan roti gandum utuh. Kandungan protein roti gandum lebih tinggi daripada beras dan terigu. Kandungan roti gandum utuh terdiri dari $70 \%$ gandum, $25 \%$ terigu, dan $5 \%$ maizena. ${ }^{28}$ Roti gandum utuh ini diberikan selama masa satu pekan pertama Ramadhan. Memasuki Ramadhan pekan kedua, racikan ingredience roti gandum ditambah menjadi: 70\% gandum, 25\% terigu, dan 5\% maizena, serta kacang tanah dan habbatussawda'/jintan hitam. Jadi, roti gandum ini sangat sehat untuk dikonsumsi, dan bagus untuk meningkatkan daya tahan tubuh, karena selain terdiri dari gandum utuh, dan maizena, juga di dalamnya terkandung habbatussawda'/jintan hitam yang berfungsi meningkatkan imun tubuh.

\section{b. Pengaturan tempat tinggal selama lockdown}

Pembatasan Sosial Berskala Besar(PSBB) di Indonesia di awali oleh Daerah Khusus Ibukota Jakarta. DKI Jakarta telah melaksanakan detail PSSB, berharap mudahmudahan pelaksanaan detail ini berjalan dengan baik. Diharapkan dengan PSBB usaha penanganan wabah corona terasa kuat, dan besar pengaruhnya untuk memutus mata rantai penyebaran covid-19 khususnya di Jakarta.

Seluruh karyawan dan sivitas Ma'had Al-Zaytun tidak boleh ada yang keluar masuk kampus Ma'had Al-Zaytun selama masa PSBB, semuanya di dalam kampus Ma'had Al-Zaytun tanpa terkecuali. Hal ini dimaksudkan untuk karantina kesehatan. Sebenarnya terkait lockdown ini telah diatur dalam pasal 9 Undang-Undang Nomor 6 Tahun 2018 tentang kekarantinaan kesehatan. Karantina bertujuan melindungi masyarakat dari penyakit dan atau faktor resiko kesehatan masyarakat yang berpotensi menimbulkan kedaruratan kesehatan masyarakat, mencegah dan menangkal penyakit, meningkatkan ketahanan nasional di bidang kesehatan masyarakat, memberikan perlindungan dan kepastian hukum bagi masyarakat dan petugas kesehatan. ${ }^{29}$

Sebagai bagian dari masyarakat dunia, Indonesia juga berkewajiban untuk melakukan cegah tangkal terhadap terjadinya Kedaruratan Kesehatan Masyarakat yang meresahkan dunia sebagaimana diamanatkan dalam regulasi Internasional di

\footnotetext{
27 Taushiyah Dzikir Jum'at Syaykh Al-Zaytun, 24 April 2020.

${ }_{28}$ Taushiyah Dzikir Jum'at Syaykh Al-Zaytun, 24 April 2020.

${ }^{29}$ Undang-Undang Nomor 6 Tahun 2018 tentang kekarantinaan kesehatan.
} 
bidang kesehatan. Dalam melaksanakan amanat ini Indonesia harus menghormati martabat hak asasi manusia, dasar-dasar kebebasan seseorang, dan penerapannya secara universal. ${ }^{30}$ Begitupun Syaykh Al-Zaytun dan sivitas Ma'had Al-Zaytun terpanggil untuk melakukan cegah tangkal terjadinya Kedaruratan Kesehatan Masyarakat yang meresahkan masyarakat Indonesia dengan melakukan lockdown sebagaimana yang dilakukan oleh DKI Jakarta dan sekitarnya.

Khusus karyawan penyedia makanan harus ditempatkan pada satu tempat yang khusus. Tidak bercampur dengan karyawan yang bekerja pada bagian pelaksanaan pembangunan. Satu kamar berukuran $12 \mathrm{~m}$ × $8 \mathrm{~m}$ maksimal dihuni oleh 8-10 orang saja. Sarana kebersihan, baik air, maupun kamar mandi ditata ulang. Tidak ada yang mandi keluar dari kamar.

Setiap penghuni kamar bertanggung jawab membersihkan kamarnya setiap pagi dan petang. Ada petugas yang menyemprotkan disinfektan setiap kamar yang dihuni. Kamar untuk petugas penyedia makanan harus jauh dari asrama pelajar. Juga ditetapkan untuk karyawan non-kitchen harus jauh dari petugas kitchen dan penyaji makanan. Hal ini merupakan upaya kehati-hatian, mengingat karyawan penyedia makanan memiliki peran yang penting dalam penyajian makanan, jadi harus benarbenar steril.

Bagian keamanan, tidak boleh ada yang keluar dari kampus Ma'had AlZaytun. Bagian keamanan yang sedang cuti di luar tidak boleh masuk ke lokasi kampus Ma'had Al-Zaytun. Kamar bagian keamanan ada yang di tempat pelaksana penyedia makanan dan sebagian ada yang di tempat pelaksana pembangunan umum. Petugas keamanan yang bertugas di asrama mengontrol kegiatan pelajar dan harus bertanggungjawab atas keamanan asrama. ${ }^{31}$

Guru selama masa PSBB harus tinggal di dalam kampus Ma'had Al-Zaytun. Tidak boleh pulang pergi ke rumahnya. Jika ada suami istri yang menjadi guru, maka istri di rumah. Guru laki-laki di dalam kampus Ma'had Al-Zaytun tanpa terkecuali. Bagi siapapun yang tidak taat terhadap peraturan ini dipersilakan keluar, tidak boleh masuk lagi ke kampus dan tidak mengajar lagi di Ma'had Al-Zaytun.

Pembelajaran berjalan seperti biasa, karena Ma'had Al-Zaytun sudah merupakan bentuk isolasi. Dalam rangka phisical distancing, kelas yang efektif diduduki oleh 19 sampai 20 pelajar. Ruang kelas dengan ukuran $9 \mathrm{~m} \times 10 \mathrm{~m}=90 \mathrm{~m}$ hanya punya hak $90 / 20=$ empat setengah meter per orang atau 88/20 = empat meter per orang. Jadi, tiap kelas maksimum 20 pelajar. Kelas ditata ulang, udara yang masuk mengandung $\mathrm{O} 2$, udara yang keluar mengandung $\mathrm{Co}$, maka setiap kelas harus ada hexos fan untuk menyedotnya. Kelas dan asrama tidak perlu AC, karena AC sudah cukup digantikan oleh tanaman-tanaman yang ada. Karbon dioksida(Co2) nya diolah

\footnotetext{
30 Nur Rohim Yunus, Annissa Rezki. (2020). Kebijakan Pemberlakuan Lockdown Sebagai Antisipasi Penyebaran Corona Virus Covid-19. Jurnal Salam, Volume 7 No. 3, hlm. 7-8.

31 Taushiyah Syaykh Al-Zaytun berkaitan dengan kondisi terkini Selasa, 24 Maret 2020.
} 
oleh tanaman-tanaman (pohon-pohon yang besar) yang ada di sekitar kampus dan asrama Ma'had Al-Zaytun. ${ }^{32}$

Syaykh Al-Zaytun menghimbau kepada seluruh sivitas Ma'had al-Zaytun wajib mengikuti semua peraturan yang ada di kampus Ma'had Al-Zaytun. Hal ini dilakukan demi untuk kesehatan bersama. Tidak ada demokrasi dan toleransi dalam hal mentaati semua ini. Sebab tidak bisa bekerja tanpa kesehatan. Tidak bisa bekerja jika kesehatan tidak terjamin. Beliau menghimbau berulang kali agar semuanya taat, tidak ada yang melanggar, ini demi kesehatan bersama. Kurun waktu lockdown mengikuti Jakarta, karena semua ini mengalirnya dari episentrum Jakarta. ${ }^{33}$

\section{c. Pengaturan dalam hal antisipasi daya tahan tubuh}

Sistem imun sangat penting bagi tubuh, dengannya tubuh dapat terlindungi dari berbagai serangan virus dan penyakit, termasuk COVID-19. Hal ini berdasarkan tindakan perlindungan dasar Internasional (WHO) terhadap COVID-19 yaitu ${ }^{34}: 1$ ). Sering mencuci tangan, secara teratur, dan benar-benar membersihkan tangan dengan bahan yang berbahan dasar alkohol dengan cara menggosok atau mencucinya dengan sabun dan air mengalir; 2). Pertahankan jarak sosial, setidaknya 1 meter (3 kaki), jaga jarak antara satu orang dengan yang lainnya, dan siapa saja yang batuk atau bersin; 3). Hindari menyentuh mata, hidung dan mulut, karena sekali terkontaminasi, tangan dapat memindahkan virus melalui mata, hidung atau mulut. Dari sinilah, virus dapat masuk ke tubuh dan membuat seseorang sakit.; 4). Lakukan cara-cara kebersihan pernafasan, pastikan orang-orang di sekitar mengikuti kebersihan pernafasan yang baik, yang berarti menutup mulut dan hidung dengan siku atau jaringan yang tertekuk saat batuk atau bersin, kemudian segera buang tisu bekas; 5). Jika mengalami demam, batuk dan kesulitan bernapas, segera cari perawat medis dengan cepat, atau tinggal di rumah jika merasa tidak sehat, dan cari perawatan medis dengan menelepon perawat/petugas medis. 6). Tetap terinformasi dan ikuti saran penyedia layanan kesehatan setempat. ${ }^{35}$

Dalam hal pelayanan kesehatan, Ma'had Al-Zaytun memiliki klinik kesehatan yang dinamakan Perkhidmatan Kesihatan. Klinik ini melayani pelayanan kesehatan 24 jam. Dari exponent, guru maupun karyawan, sampai pelajar jika sakit dirawat di Perkhidmatan Kesihatan (P.K.). Hal ini menunjukkan bahwa Ma'had Al-Zaytun menjamin kesehatan para karyawan maupun pelajar. Dengan adanya Perkhidmatan Kesihatan berarti Ma'had Al-Zaytun telah melaksanakan isi Pasal 166 ayat 1 dan 2 Undang-Undang Nomor 36 Tahun 2009 Tentang Kesehatan yang menyatakan bahwa

32 Taushiyah Dzikir Jum'at Syaykh Al-Zaytun, 10 April 2020.

33 Taushiyah Dzikir Jum'at Syaykh Al-Zaytun, 10 April 2020.

${ }^{34}$ World Health Organization, Coronavirus disease (COVID-19) advice for the public. Retrieved from who.int: https:/www.who.int/emergencies/diseases/novel-coronavirus-2019/advice-for-public, 16 April, 2020.

35 World Health Organization, Coronavirus disease (COVID-19) advice for the public. Retrieved from who.int: https:/www.who.int/emergencies/diseases/novel-coronavirus-2019/advice-for-public, 16 April, 2020. 
ayat (1): "Majikan atau pengusaha wajib menjamin kesehatan pekerja melalui upaya pencegahan, peningkatan, pengobatan dan pemulihan serta wajib menanggung seluruh biaya pemeliharaan kesehatan pekerja." ${ }^{36}$ Undang-Undang ini merupakan jaminan pemberian hak kesehatan pekerja. ${ }^{37}$ Dalam rangka mengatasi masalah kesehatan, kedepannya Syaykh Al-Zaytun akan menyiapkan dokter, dan fasilitas kesehatan yang lebih banyak. Biayanya dipersiapkan dengan menanam pisang, pepaya, padi, tebu, wijen dan jagung sebanyak-banyaknya. ${ }^{38}$

Dari penyampaian Taushiyah Syaykh Al-Zaytun, fakta prakteknya adalah Syaykh Al-Zaytun menyusun dan menetapkan protokol antisipasi (penanganan) berbagai perkembangan sebaran penyakit menular yang disebabkan oleh penularan virus, bakteri, dan mikroba lainnya di kampus Ma'had Al-Zaytun sebagai berikut: Penanggungjawab Utama (Umum) Syaykh Al-Zaytun Dr. Al-Ustadz (Hon. M.S.U.) A.S. Panji Gumilang, M.P., Ketua Pelaksana adalah Ketua Yayasan Pesantren Indonesia Imam Prawoto, S.E., M.B.A., Wakil Ketua Pelaksana (Pimpinan Perkhidmatan Kesihatan) dr. Dani Kadarisman, MARS., Juru Bicara dr. Dani Kadarisman, MARS., Pelaksana Harian; untuk santri: Drs. Budi Satrio, Apt., M.Pd. (Ketua Majelis Guru), Drs. Purnomo (Wakil Ketua Majelis Guru), Drs. Suherman (Wakil Kepala Sekolah Madrasah Aliyah), Rizal Eka Sumadya (Wakil Kepala Sekolah Madrasah Tsanawiyah) Moch. Iqbal Aulia, S.Sos (Wakil Kepala Sekolah Madrasah Ibtidaiyah), Mar'atu Soleha, S.Pd.I. (Kepala PAUD), Dr. Henri Peranginangin T, S.A.N., M.Kes., (Wakil Rektor Administrasi IAI AL-AZIS), Dr. Ir. Bambang TriyoV6ga, M.T.(untuk Relawan LKM MRLA), Zaenal Abidin (untuk Relawan non LKM), Abdul Halim S.Sos., M.P. (Bidang kerjasama dan penghubung kepada Rumah Sakit Santo Borromeus Bandung), dan lain-lainnya sebagaimana terlampir dalam Kepanitiaan Protokol antisipasi (penanganan) berbagai perkembangan sebaran penyakit menular yang disebabkan oleh penularan virus, bakteri, dan mikroba lainnya di kampus Ma'had Al-Zaytun yang ditetapkan pada tanggal 19 Maret 2020.39

Seluruh sivitas Ma'had Al Zaytun wajib mengikuti vaksin flue. Hal ini dimaksudkan untuk meningkatkan daya kekebalan tubuh. Jika daya tahan tubuh bagus maka imun tubuh dapat menangkal berbagai macam virus, termasuk virus corona. Vaksinasi dimulakan pada hari Selasa, 17 Maret 2020 di Perkhidmatan Kesihatan jam 08.30 sd. selesai.

Seluruh sivitas Ma'had Al Zaytun juga wajib berolahraga tiap hari minimal satu jam. Olah raga yang dilakukan di antaranya adalah olah raga kesehatan kaki (OKK) dengan berjalan kaki setengah lari, senam kesehatan jasmani, ataupun bersepeda. Hal ini dimaksudkan, dengan berolahraga, daya tahan tubuh akan meningkat, sehingga terjauhkan dari serangan virus, dan penyakit. Jika kekebalan

36 Undang-Undang Nomor 36 Tahun 2009 Tentang Kesehatan Pasal 166 ayat 1 dan 2.

37 Rahmatullah, Indra. (2020). Jaminan Hak Kesehatan Pekerja Work from Office Selama Masa PSBB Covid-19. 'Adalah: Buletin Hukum dan Keadilan, 1.

38 Taushiyah Dzikir Jum'at Syaykh Al-Zaytun, 10 April 2020.

39 Yayasan Pesantren Indonesia, Kepanitiaan Protokol antisipasi (penanganan) berbagai perkembangan sebaran penyakit menular yang disebabkan oleh penularan virus, bakteri, dan mikroba lainnya di kampus Ma'had AlZaytun, ditetapkan pada tanggal 19 Maret 2020. 
tubuh manusia bagus, maka sistem imun itu akan mampu membunuh virus dan bakteri yang menyerang tubuh. Sebaliknya jika kekebalan tubuh menurun apabila tubuh terserang virus dan bakteri, maka system imun tidak mampu melawannya, dan tubuh rentan terhadap penyakit.

\section{d. Pengaturan dalam hal lingkungan yang sehat}

Semua bangunan yang ada di kampus Ma'had Al Zaytun di kelilingi oleh pepohonan yang lebat dan tinggi. Pepohonan ini berfungsi sebagai penahan gedung dari terpaan angin kencang/puting beliung sekaligus penghasil oksigen (O2). Lingkungan pun teduh, asri, dan bebas polusi udara.

Perputaran udara yang masuk ke ruangan dan udara yang keluar ruangan disedot oleh hexos fan. Pada tiap kelas dan asrama, dipasang hexos sebagai bentuk pembangunan renovasi gedung sekolah dan asrama. Udara kotor yang keluar dari ruangan diolah oleh pohon-pohon yang ada di sekitar gedung..$^{40}$ Dengan demikian lingkungan Ma'had Al-Zaytun udaranya selalu bersih, segar, dan menyehatkan.

Seluruh sivitas Ma'had Al-Zaytun dalam keadaan sehat, tidak ada yang terjangkit corona, maka seluruh sivitas Ma'had Al-Zaytun dapat melakukan aktifitas regular dengan mengikuti protokol COVID-19 dari Kementrian Kesehatan Indonesia. Protokol dari Kementrian Kesehatan Indonesia tersebut adalah jika masyarakat berada di lokasi yang masih bersih dari COVID-19, dan area tersebut mengikuti perlindungan dasar terhadap COVID-19, seperti menjaga jarak sosial, menjaga dan memantau pintu masuk utama berdasarkan protokol COVID-19,41 menyemprotkan cairan disinfektan dua kali seminggu ke semua tempat tinggal, memberikan vaksin influenza kepada masyarakat yang tinggal di daerah itu ${ }^{42}$; maka hal tersebut membuat masyarakat di lokasi itu masih dapat melakukan aktifitas seperti; sholat Jum'at berjamaáh dengan menjaga jarak 3 kaki dari satu jamaah ke yang lain, siswa masih bersekolah dengan jarak 1 meter antara satu siswa dengan siswa yang lain, pekerja dapat bekerja di tempat reguler mereka dengan disiplin mengikuti protokol COVID-19, dan para petani pun dapat melakukan yang terbaik dalam memanen ladang mereka untuk menyajikan kebutuhan makanan. ${ }^{43}$

Menurut protokol dari Kementrian Kesehatan Indonesia dalam Penanganan COVID-19 yang telah dijelaskan di atas, maka seluruh penghuni Ma'had Al-Zaytun, utamanya santriwan-santriwati memiliki kepercayaan diri (confident) yang tinggi untuk melakukan aktifitas regular. Seperti; dapat melakukan sholat Jum'at berjamaáh

\footnotetext{
${ }^{40}$ Taushiyah Dzikir Jum'at Syaykh Al-Zaytun, 10 April 2020.

${ }^{41}$ Kementrian Kesehatan Indonesia, Penanganan COVID-19 Protokol Pintu Masuk Wilayah Indonesia (Bandara, Pelabuhan, PLBDN). Retrieved from infeksiemerging.kemkes.go.id: https://infeksiemerging.kemkes.go.id/download/Protokol-Perbatasan-COVID-19.pdf. 2020.

42 Vaksin ini meningkatkan sistem kekebalan tubuh manusia, sebagai salah satu ikhtiar (upaya) dalam menghadapi COVID-19.

${ }^{43}$ Kementrian Kesehatan Indonesia, Penanganan COVID-19 Protokol Pintu Masuk Wilayah Indonesia (Bandara, Pelabuhan, PLBDN). Retrieved from infeksiemerging.kemkes.go.id: https://infeksiemerging.kemkes.go.id/download/Protokol-Perbatasan-COVID-19.pdf. 2020.,
} 
dengan menjaga jarak 3 kaki dari satu jamaah ke yang lain, bahkan untuk saat ini jarak antara satu jamaah dengan jamaah lain, samping kanan dan kiri jaraknya dua meter, depan dan belakang jaraknya 4 meter. Santri masih dapat bersekolah dengan jarak 1 meter antara satu santri dengan santri yang lainnya, bahkan sekarang jaraknya empat setengah meter atau empat meter per santri.

\section{Strategi ruhiyah}

Sivitas Ma'had Al-Zaytun tetap melakukan ibadah regular hingga shalat jum'at berjamaah, dan juga ibadah pada bulan ramadhan. Hal ini disusul dengan adanya kebijakan Pemerintah daerah Provinsi Jawa Barat; memberikan tatacara shalat berjamaah dengan baik di masa wabah ini. Ma'had Al-Zaytun mengikuti tatacara dan protocol yang diterbitkan oleh WHO; organisasai kesehatan Internasional pada organisasi Perserikatan Bangsa-Bangsa (PBB) dan memaknai ketetapan Pemerintah DKI Jakarta dalam hal PSBB nya, dan ketetapan BNPB yang diketuai oleh Jendral Beni, serta PSBB Pemerintah Provinsi Jawa Barat. ${ }^{44}$ Kegiatan shalat di masjid selama Ramadhan jaraknya ditambah. Samping kanan dan kiri jaraknya dua meter, depan dan belakang jaraknya 4 meter. Masjid digunakan untuk shalat berjamaah para exponent, guru dan karyawan. Sedangkan guru, pembimbing, dan pelajar shalat berjamaah di aula asrama. Tiap lantai memiliki aula yang sangat luas. Jadi aula ini dapat menampung penghuni asrama setiap lantai untuk shalat berjamaah. Jadi, bagi sivitas Ma'had Al-Zaytun pandemic corona tidak dijadikan suatu halangan untuk beribadah di bulan suci ramadhan.

Koordinasi pelaksanaan shalat tarawih sudah jelas. Setiap yang mengikuti tarawih di masjid dicatat berapa jumlahnya dan namanya, kemudian disetor kepada koordinator masjid. Begitu juga pelaksanaan tarawih di asrama dicatat berapa jumlahnya dan namanya, kemudian disetor kepada koordinator asrama (administrasi dilakukan oleh Majelis guru). Juga ditentukan koordinator tadarus sebagai penanggung jawab yang menerima catatan untuk jumlah tadarus yang dicapai. ${ }^{45}$

Tadarus harus tetap dilakukan oleh Sivitas Ma'had Al-Zaytun secara intensif. Minimal dalam 10 hari sudah selesai 30 juz. Jadi dalam satu ramadhan ini perorang minimal akan khatam 3 kali. Di Masyikhah (kantor Yayasan Pesantren Indonesia dan aula pertemuan) juga dilakukan tadarus secara intensif. Jarak tadarus antara satu orang dengan yang lainnya adalah 5 meter.

Dari paparan di atas dapat kita ketahui bahwa Syaykh Al-Zaytun sangat concern dan serius dalam melakukan protokol pelaksanaan ibadah dalam masa Covid19 dan ibadah di bulan ramadhan. Sebagaimana yang kita ketahui, beribadah di bulan suci ramadhan pahalanya berlipat ganda. Selain itu juga amal shaleh yang dilakukan itu dapat digunakan sebagai wasilah/perantara dalam berdoa agar doa yang dipanjatkan segera terkabul. Dalam masa pandemic corona ini, semua orang berdoa

\footnotetext{
44 Taushiyah Dzikir Jum'at Syaykh Al-Zaytun, 24 April 2020.

45 Taushiyah Dzikir Jum'at Syaykh Al-Zaytun, 17April 2020.
} 
harap-harap cemas dengan wasilah amal shaleh itu supaya pandemic corona segera hilang dari muka bumi.

\section{Strategi psikologis}

Secara psikologis daya tahan tubuh manusia akan kuat jika selalu berpikir dan bertindak positif. Di antaranya; berbaik sangka, sabar, syukur, ikhlas dan jujur. Begitu pun sebaliknya daya tahan tubuh akan melemah saat berpikir dan bertindak negatif. Di antaranya; pikiran dikuasai dengki, fitnah, iri, hasut, ujaran kebencian dan cacian, seks bebas, seks sesama jenis, dan narkoba.

Perkuatlah ketahanan tubuh dengan selalu berbaik sangka, husnudzon, ikhlas, dan tawakkal. Hilangkan rasa iri, caci maki, dengki, ujar kebencian, fitnah dan kekerasan, narkoba, dan penyimpangan seksual. Covid-19 telah mendidik kita bahwa Virus Corona mudah menyerang mereka yang daya tahan tubuhnya lemah. ${ }^{46}$

Dari uraian di atas dapat kita ketahui bahwa Syaykh Al-Zaytun sangat memperhatikan sisi psikologis sivitas Ma'had Al-Zaytun. Beliau menghimbau agar seluruh sivitas Ma'had Al-Zaytun untuk selalu berpikir dan berperilaku positif supaya daya tahan tubuh selalu terjaga. Dengan demikian diharapkan daya tahan tubuh yang bagus dapat membunuh segala macam virus, termasuk virus corona.

\section{Kontribusi Syaykh Al-Zaytun dan Sivitas Ma'had Al-Zaytun terhadap lingkungan sekitarnya}

Kampus Ma'had Al-Zaytun memiliki lingkungan yang aman dan ternaungi dengan baik. Banyak pepohonan, udara bersih, listrik, air, makanan, dan minuman semua tercukupi. Mungkin ini yang dinamakan Ghani, yang artinya semua cukup. Hal ini menjamin sivitas Ma'had Al-Zaytun untuk hidup sehat. Sementara itu saat ini di luar sana, semua tidak mencukupi, sedangkan pekerjaan terbatas. ${ }^{47}$ Di luar kampus Ma'had Al-Zaytun hampir semua orang saat ini merasakan stress karena ketidakcukupan atau bahkan kekurangan. Sedangkan di kampus Ma'had Al-Zaytun semuanya tercukupi.

Di luar sana pekerjaan banyak yang diputus/di PHK. Di sini, di kampus Ma'had Al-Zaytun tidak ada yang putus kerja, gaji karyawan, guru, dan dosen semuanya tidak putus. Bahkan gaji ke-13 tetap dicairkan. Maka Syaykh Al-Zaytun menghimbau seluruh sivitas Ma'had Al-Zaytun di bulan Ramadhan ini harus melakukan Harakah Ramadhan/bakti Ramadhan.

Karyawan, guru, dan dosen sebanyak 6 kali lipat dari biasanya, sedangkan untuk para pelajar 3 kali lipat dari biasanya. Hal ini merupakan wujud rasa syukur atas nikmat yang dirasakan berupa terpenuhinya semua kebutuhan di tengah-tengah pandemic corona ini.

46 Taushiyah Syaykh Al-Zaytun dalam Renungan Jum'at 1 Mei 2020.

47 Taushiyah Dzikir Jum'at Syaykh Al-Zaytun, 24 April 2020. 
Dalam kampus ada 7000 orang, sejumlah itulah masyarakat yang akan disantuni oleh Ma'had Al-Zaytun. Santunan yang akan diberikan cukup untuk makan selama 2 bulan. Santunan tersebut berupa beras, gula, minyak goreng, garam, dan bahan lainnya. Hal ini merupakan bukti kepedulian Syaykh Al-Zaytun dan Sivitas Ma'had Al-Zaytun terhadap masyarakat sekitar. Inilah hakikat kemanusiaan yang adil dan beradab, pun pula dengan inilah kita memaknai Al Qur'an. ${ }^{48}$

Sivitas Ma'had Al-Zaytun terutaman para karyawan di bulan Ramadhan ini dianjurkan untuk bekerja extra, yaitu kerja volunteer pada masa cuti. Hal ini untuk mendapatkan tambahan gaji dalam rangka menunaikan bakti ramadhan. Bekerja extra juga supaya mampu berpartisipasi mewujudkan ath'amahum min juu', mengatasi rasa lapar dan supaya mampu berpartisipasi mewujudkan aamanahum min khauf, terbebas dari kekhawatiran kelaparan. Tentu bekerja di lapangan terbuka tetap mengikuti protokol.

Di dalam bulan Ramadhan ada Gerakan berupa harakah Ramadhan, yaitu zakatul fithri maupun zakatul amwal. Semuanya dikoordinir dan masuk ke kas, setelah terkumpul didistribusikan kepada masyarakat yang membutuhkan. Hitungannya tetap seperti yang telah berjalan, karena yang ditetapkan itu yang elastis, di zaman dahulu sampai pada dasawarsa yang akan datang pun masih tetap relevan. Untuk guru dan santri koordinatornya adalah majelis guru. Pelaksananya kepala sekolah. ${ }^{49}$

Akibat covid-19 produk pertanian di Indonesia berkurang. Ma'had Al-Zaytun menyiapkan 100.000 tanaman pisang yang akan mampu mengurangi kekurangan vitamin di negara kita. Siapapun yang mempersiapkan pertanian di musim pandemic ini, niscaya nilai ekonominya akan baik. Posisi geografis Ma'had Al-Zaytun mendukung, Indramayu terletak di pintu dapur Jakarta. Apapun barangnya yang disetor ke Jakarta akan habis. ${ }^{50}$

Dari uraian di atas dapat dipahami bahwa Syaykh Al-Zaytun sangat peduli terhadap sivitas Ma'had Al-Zaytun dan masyarakat sekitar. Hal ini terbukti dalam himbauan Beliau kepada sivitas Ma'had Al-Zaytun untuk melakukan harakah ramadhan dan bekerja ekstra di bulan ramadhan ini dalam rangka persiapan logistic supaya terbebas dari kekhawatiran terhadap kelaparan.

\section{Kesimpulan}

Pandemic corona yang melanda dunia tak kunjung reda. Diperlukan penanganan dan pencegahan yang serius dari pemerintah dan seluruh elemen masyarakat, tak terkecuali para pemimpin dan public figur di negeri ini. Dalam hal ini, Syaykh Al-Zaytun sebagai pemimpin pondok pesantren telah memberikan contoh konkrit dalam pencegahan COVID-19 di lingkungan Ma'had Al-Zaytun secara serius dan konprehensif. Pencegahan COVID-19 dilakukan dengan berbagai strategi dan

48 Taushiyah Dzikir Jum'at Syaykh Al-Zaytun, 24 April 2020.

49 Taushiyah Dzikir Jum'at Syaykh Al-Zaytun, 24 April 2020.

50 Taushiyah Dzikir Jum'at Syaykh Al-Zaytun, 24 April 2020. 
kebijakan yang harus dilaksanakan oleh sivitas Ma'had Al-Zaytun. Di antaranya Strategi fisik, strategi ruhiyah, dan strategi psikologis.

Strategi fisik berupa Pengaturan dalam hal logistic/makanan, pengaturan tempat tinggal dan tempat kerja selama lockdown, pengaturan dalam hal antisipasi daya tahan tubuh, dan pengaturan dalam menciptakan lingkungan yang sehat. Strategi ruhiyah dilakukan dengan memperbanyak ibadah di bulan ramadhan. Di antaranya memperbanyak membaca Al-qur'an, dzikir asmaul husna dan nabi, serta shalat tarawih. Strategi psikologis dilakukan dengan cara memperkuat ketahanan tubuh yaitu dengan selalu berpikir dan bertindak positif; berbaik sangka, ikhlas, sabar, syukur, jujur dan tawakkal. Dengan demikian dapat diharapkan daya tahan tubuh bertambah kuat dan dapat menangkal berbagai macam bakteri dan virus, termasuk COVID-19.

Di tengah merebaknya pandemic corona ini Ma'had Al-Zaytun berkontribusi terhadap masyarakat sekitar. Hal ini di antaranya dengan melakukan harakah ramadhan pada bulan ramadhan yaitu menghimpun zakatul fithri maupun zakatul amwal dari seluruh sivitas Ma'had Al-Zaytun yang nantinya akan disalurkan kepada masyarakat sekitar yang membutuhkannya. Selain itu Syaykh Al-Zaytun dan sivitas Ma'had AlZaytun juga giat mempersiapkan pertanian di masa pandemic corona ini untuk menopang produksi pertanian di Negara Indonesia yang menurun pada masa pandemic COVID-19 ini.

Di Indonesia terdapat puluhan ribu ormas, perguruan tinggi, sekolah, dan pondok pesantren, baik besar maupun kecil. Jika strategi dan kebijakan Syaykh AlZaytun dalam menghadapi pandemic corona ini diikuti dan di implementasikan oleh para pemimpin ormas, perguruan tinggi, sekolah, dan pondok pesantren di seluruh Indonesia, maka dapat diharapkan hal ini akan sangat membantu pemerintah Indonesia dalam mengatasi wabah COVID-19 ini.

\section{Referensi:}

Alma, Buchari, Kewirausahaan, (Bandung: Alfabeta, 2013 M.)24-25.

Bygrave, William D., The Portable MBA in Intrepreneurship, (New York: John Willey \& Sons 1994 M.).

Idri, Hadis Ekonomi, (Jakarta: Prenada Media, 2016 M.)

Irawan, Prasetya, Penelitian Kualitatif \& Kuantitatif untuk Ilmu-ilmu Sosial, (Jakarta: DIA FISIP UI, 2006 M.).

Kementrian Kesehatan Indonesia, Penanganan COVID-19 Protokol Pintu Masuk Wilayah Indonesia (Bandara, Pelabuhan, PLBDN). Retrieved from infeksiemerging.kemkes.go.id:https://infeksiemerging.kemkes.go.id/downloa d/Protokol-Perbatasan-COVID-19.pdf. 2020.

Lembaga Kesejahteraan Masjid Masjid Rahmatan Lil 'alamiin, Majalah Al-Zaytun dalam periode $1999-2012$. 
Al-Maraghi, Ahmad Al-Mustafa, Tafsir Al-Maraghi, (Semarang: PT. Karya Toha Putra Semarang:1993), jilid 27.

Moleong, Lexy J. Metodologi Penelitian Kualitatif (Bandung: PT. Remaja Rosda Karya, 2004).

Rahmatullah, Indra. (2020). Jaminan Hak Kesehatan Pekerja Work from Office Selama Masa PSBB Covid-19. 'Adalah: Buletin Hukum dan Keadilan, 1.

Al-Sabuni, Muhammad 'Ali, Rawai' al-Bayan Tafsìr Ayat al-Ahkām min al-Qur'an (Jakarta: Dar al-Kutub al-Islamiyyah, 1999), Jilid 1, 209.

Sukirno, Sadono, et al. Pengantar Bisnis, (Jakarta: Prenadamedia, 2004 M.)

Tarmudji, Tarsis, Prinsip-prinsip Wirausaha, (Yogyakarta: Liberty, 2003 M.)

Muh. Yunus, Islam dan Wirausaha Kreatif, (Malang: UIN Press, 2008 M.)

Taushiyah Syaykh Al-Zaytun berkaitan dengan kondisi terkini Selasa, 24 Maret 2020.

Taushiyah Dzikir Jum'at Syaykh Al-Zaytun, 10 April 2020.

Taushiyah Dzikir Jum'at Syaykh Al-Zaytun, 17 April 2020.

Taushiyah Dzikir Jum'at Syaykh Al-Zaytun, 24 April 2020.

Taushiyah Syaykh Al-Zaytun dalam Renungan Jum'at 1 Mei 2020.

Undang-Undang Nomor 6 Tahun 2018 tentang kekarantinaan kesehatan.

Undang-Undang Nomor 36 Tahun 2009 Tentang Kesehatan Pasal 166 ayat 1 dan 2.

World Health Organization, Coronavirus disease (COVID-19) advice for the public.

Retrieved from who.int: https:/www.who.int/emergencies/diseases/novelcoronavirus-2019/advice-for-public, 16 April, 2020.

Yayasan Pesantren Indonesia, Al-Zaytun Pusat Pendidikan Pengembangan Budaya Toleransi dan Perdamaian (Indramayu: Al-Zaytun Press, 2014).

Yayasan Pesantren Indonesia, Kepanitiaan Protokol antisipasi (penanganan) berbagai perkembangan sebaran penyakit menular yang disebabkan oleh penularan virus, bakteri, dan mikroba lainnya di kampus Ma'had Al-Zaytun, ditetapkan pada tanggal 19 Maret 2020.

Yunus, Nur Rohim; \& Rezki, Annissa. (2020). Kebijakan Pemberlakuan Lockdown Sebagai Antisipasi Penyebaran Corona Virus Covid-19. Jurnal Salam, Volume 7 No. 3.

Zimmerer, Thomas W. dan Scarborough, Norman, Entrepreneurship: The New Venture Formation (Prentice Hall International Inc., 1996 M.). 
Imam Prawoto, Siti Ngainnur Rohmah, Fitri Rachmiati Sunarya 


\section{Indexed by :}
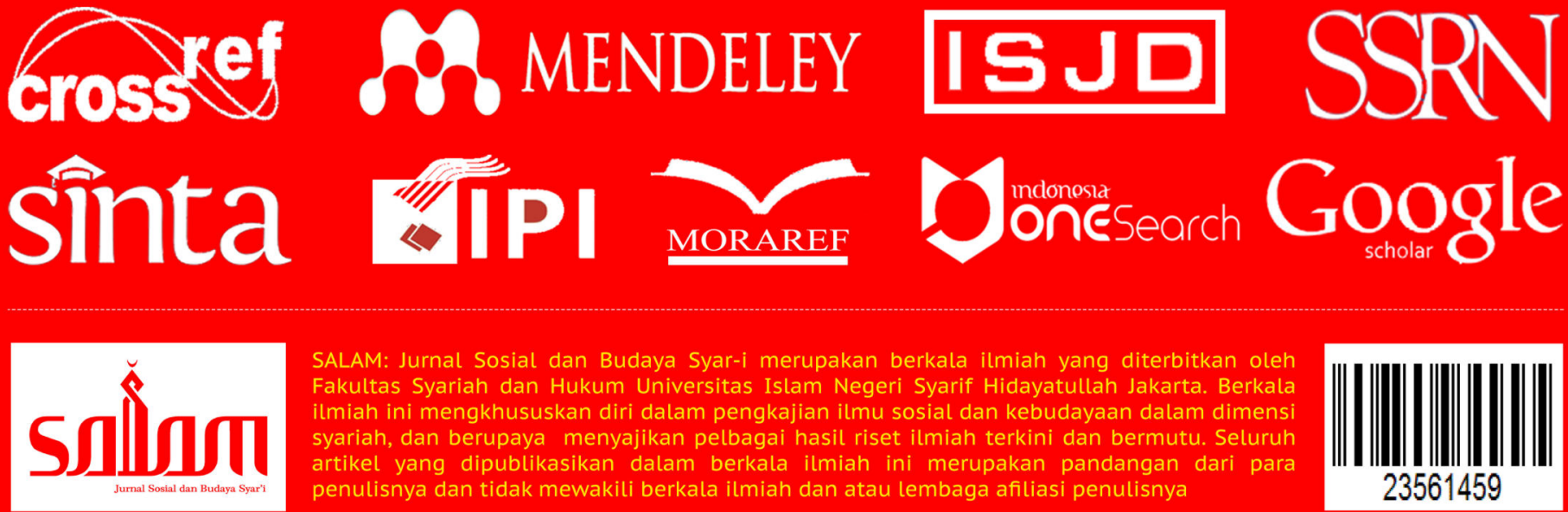

SALAM: Jurnal Sosial dan Budaya Syar-i merupakan berkala ilmiah yang diterbitkan oleh Fakultas Syariah dan Hukum Universitas Islam Negeri Syarif Hidayatullah Jakarta. Berkala ilmiah ini mengkhususkan diri dalam pengkajian ilmu sosial dan kebudayaan dalam dimensi syariah, dan berupaya menyajikan pelbagai hasil riset ilmiah terkini dan bermutu. Seluruh artikel yang dipublikasikan dalam berkala ilmiah ini merupakan pandangan dari para penulisnya dan tidak mewakili berkala ilmiah dan atau lembaga afiliasi penulisnya

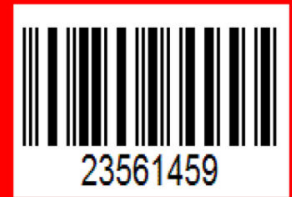

